\title{
Are Consultation and Social Justice Advocacy Similar?: Exploring the Perceptions of Professional Counselors and Counseling Students
}

\author{
Jeffry L. Moe \\ University of Houston Victoria \\ Dilani Perera-Diltz \\ Cleveland State University \\ Victoria Sepulveda \\ University of Toledo
}

\begin{abstract}
An exploratory pilot study was conducted to investigate the views of present and future counselors on whether and in what ways social justice advocacy and consultation may overlap and possibly synergize. Descriptive results indicate that study participants $(n=203)$ viewed (a) basic counseling skills, (b) problem-solving, (c) acting on behalf of clients, and (d) contextualizing client or student issues in relation to oppression as services that both consultants and advocates engage in. Practices such as diagnosis or direct action were viewed as unique to either consultation or advocacy. A multivariate analysis of covariance revealed that participants differed in their perceived similarity between consultation and advocacy based on the interaction of their practice setting and ethnic or racial identification. Implications for future research and theory are discussed.
\end{abstract}

The topic of social justice as it applies to and informs professional counseling has been addressed in the literature from many perspectives (Smith, Ng, Brinson, \& Mityagin, 2008). Scholars propose that integrating a social justice advocacy role into the core identity of professional counselors will help redress past and current societal oppression of marginalized populations (Constantine, Hage, Kindaichi, \& Bryant, 2007; Crethar, Torres Rivera, \& Nash, 2008; Hays, Dean, \& Chang, 2007; Roysircar, 2009). Present conceptions of social justice advocacy stress critical self-reflection on one's personal relationship to oppression within the 
socio-political context of the mainstream or dominant culture (Constantine et al., 2007; Crethar et al., 2008; Roysircar, 2009; Vera \& Speight, 2003). Counselors are encouraged to consider the role that their profession plays within the dominant culture (Prilleltensky \& Prilleltensky, 2003), to reconcile the role of healer with that of social change-agent (Vera \& Speight, 2003), and to advocate for macro-level, pro-social systemic change on behalf of their clients and of those suffering oppression and marginalization (Lewis, Arnold, House, \& Torporek, 2003; Prilleltensky \& Prilleltensky, 2003; Roysircar, 2009). Crethar, Torres Rivera, and Nash (2008) have identified the principles of equity, access, participation, and harmony as values that social justice advocates seek to promote via change initiatives at the individual, community, and sociocultural levels.

Though scholars continue to identify concerns regarding how the specific nature and scope of social justice advocacy for counselors will be defined (Nelson-Jones, 2002; Roysircar, 2009; Weinrach \& Thomas, 2004), in 2003 the American Counseling Association (ACA) endorsed the creation and publication of the Advocacy Competencies (Lewis et al., 2003) for professional counselors. The Summer 2009 special issue of the Journal of Counseling and Development on the Advocacy Competencies (Lewis et al., 2003) contains conceptual scholarship on how to integrate different aspects of said Competencies into counseling practice. Along with the publication of this special issue, scholarship has focused on making the case for social justice (Prilletensky \& Prilletensky, 2003; Vera \& Speight, 2003), and on synthesizing the social justice counseling paradigm with other key counseling perspectives such as multicultural theory (Constantine et al., 2007; Crethar et al., 2008) and school counseling (Bemak \& Chung, 2008; Dahir \& Stone, 2009). These conceptual and theoretical efforts are useful for describing how and why social justice is a fundamental premise for professional counseling in the $21^{\text {st }}$ century. Further efforts to articulate the paradigm of social justice advocacy into other knowledge domains salient to professional counseling are warranted, especially in terms of creating empirically-based scholarship to texture the literature base. Of 26 articles indexed under the subjects of social justice and social advocacy published in the Journal of Counseling and Development between 1987 and 2009, only two were based on data collection and analysis. Of the eight articles published in Counselor Education and Supervision on social justice advocacy during the same time period, only two were empirical investigations with one of these articles being a content analysis of the journal (Smith et al., 2008).

Along with the lack of data-driven scholarship pertaining to social justice advocacy in the counseling literature, there is some evidence that practitioners and students have mixed or conflicting reactions to addressing issues of social power and privilege as these apply to counseling (Bemak \& Chung, 2008; Hayes et al., 2007; Weinrach \& Thomas, 2004). Two phenomena articulated in the literature include counselors' resistance to addressing social privilege as an issue relevant to counseling (Arredondo, Tovar-Blank, \& Parham, 2008; Hayes et al., 2007) and a desire by counselors to have proponents of social justice advocacy and multicultural theory explain in greater detail how to implement advocacy into daily practice (Nelson-Jones, 2002; Weinrach \& Thomas, 2004). For example, Ludlow, Enterline, and Cochran-Smith (2008) identified that student teachers' beliefs about social justice changed over the course of their education, with more experienced student teachers evidencing greater willingness to discuss privilege and oppression both inside and outside of the classroom. Student teachers seemed more comfortable endorsing beliefs related to expression of attitudes or knowledge about oppression and were more reluctant to endorse beliefs related to actions necessary to counter or reduce oppression (Ludlow et al., 2008). In a similar vein, Hayes and colleagues (2007) described how it was easier for counseling students to agree on the need for 
advocacy, but harder for the same students to identify concrete strategies for coping with specific oppressive conditions.

Scholars have integrated the social justice advocacy paradigm into conceptually related frameworks partially to address the above phenomena (Ratts \& Hutchins, 2009). Bemak and Chung (2008) identified that the principles of systemic advocacy and of working with students to increase access to resources are evident in both the American School Counselor Association (ASCA) National Model and the ACA Advocacy Competencies (Lewis et al., 2003). Dahir and Stone (2008) articulated how advocacy principles can be infused into school counseling data collection and accountability strategies. Social justice advocacy and multicultural counseling competency share philosophical underpinnings (Crethar et al., 2008) such as attempting to redress historical oppression and to highlight how concepts of mental illness have been used to pathologize the experiences of oppressed people (Roysircar, 2009). Integrating social justice advocacy with frameworks like the ASCA National Model and the Multicultural Counseling Competencies (Arredondo et al., 1996) helps to identify concrete practices, skills, attitudes, and knowledge bases that advocates may use to facilitate social change in their role as a counselor.

\section{Social Justice and Consultation}

Along with school counseling best practice models and with multicultural theory, review of the literature reveals that scholars have identified consultation as a complementary model of practice for counselors acting as social justice advocates. Consultation for professional counselors typically involves acting on behalf of an identified client (or student) through interaction with another professional consultee or other stakeholder in the client's welfare (Brown, Pryzwansky, \& Schulte, 2010; Kampwirth, 2006; Kurpius \& Fuqua, 1993). The consultee may also be conceptualized as a system or organization that serves an identified client or student population (Brown et al., 2010; Moe \& Perera-Diltz, 2009). Practices such as preparing for entry into a consultee organization (or clarifying one's consultant role if already joined with a consultee organization) (Brown et al., 2010), developing rapport with vested stakeholders (Kurpius \& Fuqua, 1993), engaging in collaborative problem solving (Lusky \& Hayes, 2001), and evaluating the efficacy of interventions (Brown, 1993; Kampwirth, 2006) are common across various models of consultation.

Scholars have identified that consultation and social justice advocacy share conceptual grounding in modes of practice that encourage counselors to act outside of the counselor/client interaction (Holcomb-McCoy \& Bryan, 2010; Lusky \& Hayes, 2001; Ratts \& Hutchins, 2009). Practices such as collaborating with multiple stakeholder groups and identifying institutional policies that may promote marginalization of vulnerable community members are used by both consultants (Brown, 1993; Kampwirth, 2006) and advocates (Vera \& Speight, 2003) to achieve desired goals. Proponents of systemic-organizational consultation models affirm the efficacy that professional counselors and counselor educators can have when acting on behalf of the consultee and (indirectly) on behalf of clients, students, and other consumers of counseling services (Lusky \& Hayes, 2001; Moe \& Perera-Diltz, 2009). The framework of behavioral consultation is often used to conduct functional behavioral analysis and assessment (Brown et al., 2010), a practice mandated by the Individuals with Disabilities Education Act (2004) to facilitate the provision of equitable and effective services to individuals with disabilities in public schools (Kampwirth, 2006). 
Baker, Robichaud, Dietrich, Wells, and Schreck (2009) proposed that school counselor consultation is a practice domain that naturally overlaps with an advocacy perspective. Comparisons and similarities between consultation strategies and social justice advocacy were put forth by Baker and colleagues and by Holcomb-McCoy \& Bryan (2010) to support these scholars' presentations of integrated models of advocacy-based consultation. Authors Ratts and Hutchins (2009) have also highlighted how counselors-as-advocates often adopt the role of consultant to promote empowerment of clients and students. Lusky and Hayes (2001) proposed that the social justice principles of collaboration, empowerment of the disenfranchised, and acting from awareness of one's own relationship to privilege are supported by infusing a critical consultation and advocacy stance into counselors' overall concept of practice.

\section{Rationale for Current Study}

The burgeoning literature base on conceptual similarities between consultation and social justice advocacy would benefit from empirical work to investigate the relevance, utility, and application of how to further integrate these two important counseling frameworks. Providing empirical evidence to texture scholars' valuable efforts at theory building may serve to further create spaces for constructive dialogue on the topic of social justice as it applies to counselor education, training, and practice. Rather than propose a new model of social justice consultation, however, the authors were interested in exploring the views of practicing counselors and counseling students to identify potential sources of synergy and divergence between social justice advocacy and consultation. The authors also sought to add to the literature by identifying variables useful for future inquiry on the topic of how and in what ways advocacy and consultation complement each other as models for practice.

In order to partially address the phenomenon where counseling students affirmed the value of social justice advocacy but also wanted more exposure to concrete practices that could promote social justice (Hayes et al., 2009), the authors wanted to anticipate counselors' responses to the idea that practices related to consultation and to social advocacy could be integrated successfully. The authors believe that feedback about the social justice advocacy paradigm in general and how it may relate to consultation specifically as provided by practicing counselors, though vital to future attempts at model- and theory-building in this area, is lacking. A consideration of the similarities between these two frameworks also may help counselors to refine and explore legitimate differences between consultation and advocacy. Finally, investigating group differences in the perceived similarity of advocacy and consultation would help clarify what characteristics of counselors may be informing their willingness to affirm a social justice perspective and integrate it into consultation. In this vein, the authors sought to address the research questions: a) Do practicing counselors perceive that consultation and social justice advocacy as similar?; b) In what ways are consultation and social justice advocacy similar as perceived by professional counselors?; and c) What variables affect counselors' perception of the similarity between consultation and social justice advocacy? The focus of the present study is to explore the perceptions of professional counselors and counseling students in order to add to the developing literature base on the topic of how consultation and social justice advocacy are related and to elicit future directions for empirical research on consultation and social justice advocacy. 


\section{Research Variables}

Given the aforementioned synthesis of multicultural theory and of advocacy within the counseling field, the authors surmised that ethnic or racial identification could be an important variable affecting counselors' perceptions of the similarity between social advocacy and consultation. Race informs our professional perspective, and racial experiences are validated in counseling through the adoption of culturally-sensitive practices and interventions (Arredondo et al., 2008; Constantine et al., 2007) including both consultation (Brown et al., 2010) and social justice advocacy (Arredondo et al., 2008; Hayes et al., 2007). The second variable of interest to the present study involves the setting or context where counselors practice. The different settings and environmental contexts of practice influence what type of behaviors counselors use to meet the needs of their identified clients. For example, in a mental health and substance abuse treatment needs assessment study conducted with incarcerated mothers, Laux et al. (2008) identified themes of (a) continuity of care, (b) client transportation to counseling, (c) lack of access to counseling during periods of incarceration, (d) lack of low-cost and ondemand services, and (e) lack of gender-specific/gender-sensitive services as the major alcohol or other drug counseling needs of the study participants.

Similarly, the professional worldview and practices of school counselors are informed by the historical and current emphases of school counselor training on consultation, change agency, and intervention at the school-wide level (Bemak \& Chung, 2008; Dahir \& Stone, 2009; Moe \& Perera-Diltz, 2009). Therefore, based on the research questions identified above, the authors of the present study planned to review the commonalities in the ratings of study participants of select competencies or practices synthesized from the literature related to both consultation and social justice advocacy. The authors also conducted a multivariate analysis of co-variance to test if the variables of ethnic or racial identification and of practice setting would contribute to group differences in the participants' perceived similarity between consultation and social justice advocacy. Both methods of data analysis are conceived as exploratory, and the authors seek to encourage reflection and to facilitate the efforts of future scholars in creating further empirical work on the concepts presented here.

\section{Method}

\section{Participants}

The Consultation and Social Justice Survey was completed by 203 eligible participants. Of these, $160(79 \%)$ were female or female-identified and $43(21 \%)$ were male or male-identified participants. In terms of ethnic or racial identification, $172(85 \%)$ respondents indicated being from European decent, 14 (7\%) from Latino/Latina decent, 7 (3.5\%) from African descent, 6 (3\%) from multi-racial descent, 3 (1.5\%) from Tribal Native American descent, and 1 (.5\%) from East Asian descent.

The education level of the participants included 7 (3.5\%) with a Bachelor's degree, $140(69 \%)$ with a Master's degree, $3(1.5 \%)$ with a Specialist degree, and $53(26 \%)$ with a Doctoral degree. Participants' average years of college education was $9(S D=3.7$, range $=2-26)$. In terms of counseling specialty, $63(31 \%)$ were School Counselors, 57 (28\%) were Community Agency Counselors, 43 (21\%) were Counselor Educators, 15 (7.4\%) were Career Counselors, 15 (7.4\%) were Counseling Graduate Students, and 10 (4.9\%) were Substance Abuse Counselors. 
Participants' had on average $9.3(S D=9.2$, range $=0$ to 40 ) years of experience as a professional counselor.

\section{Instrumentation}

The Consultation and Social Justice Survey was composed of 21 statements that the participants were asked to categorize as being associated with consultation, advocacy, both, or neither. These 21 statements were developed by the first author by synthesizing practices identified by scholars as indicative of competence in the respective literature bases for consultation and for advocacy. Please see Table 1 for the final version of the complete survey, including research citations from which each statement was derived. The final version of the survey was distributed using the Internet via advertisement on list-serves for professional counselors. The Cronbach's internal consistency estimate for participants' responses to the 21 items was $\alpha=.81$. In addition to the 21 statements of the main survey, participant demographics of gender, race, degree type, years of experience, and years of education were requested to describe the sample. The survey itself is conceived as a pilot instrument designed to facilitate comparison of overlapping practices identified in the literature relating to both consultation and social justice advocacy. Given the numerous models, practices, and competencies identified as germane to consultation and to social justice advocacy, the survey is not conceived as an exhaustive list but as a representative one of apparently similar practices. The input of counselor educators familiar with both the consultation and social justice literature referenced (for each of the composed survey items) was solicited for initial reactions and feedback. The rationale and process for item creation and selection was explained, and the research used to synthesize the 21 items was presented to the 4 counselor educators that offered feedback about the survey and the items. There were no major revisions made as a result of this process.

\section{Procedure}

Participants were recruited through advertisement via the CESNET listserv and the electronic mailing lists of several state branches of ACA. Participants also were recruited from a list of contact e-mails purchased by the principal investigator from ACA. The ACA-generated list of 999 member e-mails was requested to be randomly selected from the membership pool by an ACA employee. The first author used a random selection feature of the SPSS program to identify 500 e-mails from this list; after forwarding an invitation to participate it was discovered that only 350 of these e-mails were still valid. Participants recruited either by the listservs or the ACA list were offered the chance to win one of two $\$ 50.00$ gift cards awarded by raffle, which was explained in the introductory letter. The recruitment strategy of advertising to various professional counseling organizations was used to capture professional counselors and counseling students with diverse practitioner backgrounds. The award was offered to increase the number of potential participants. Although it is difficult to estimate an accurate return rate due to participant recruitment through e-mail lists and other online mediums, the survey was completed by $40 \%$ of those whose e-mails were provided by the ACA. From a total of 272 participants who were recorded visiting the survey, a total of $211(78 \%)$ participants completed the survey. Of these 211 that completed, 8 participants were excluded as they did not meet the inclusion criteria based on their degree type or professional identity. The final sample in this study consisted of 203 participants. 


\section{Data Analysis}

Descriptive statistics were reviewed to gauge the characteristics of the participant sample and to partially address whether participants found the items on the survey to be practices in which both consultants and advocates would engage. A multivariate analysis of covariance (MANCOVA) was conducted to test if participants differed in their perceived similarity between consultation and social justice advocacy by the variables of ethnic or racial identification and practice setting, holding constant the effects of (a) years of experience, (b) years of college education, (c) gender, and (d) responses indicating that the participants' were unfamiliar with the resources used to create the survey. The authors used a significance level for the MANCOVA of $\alpha=.05$. Perception of similarity was defined in the multivariate sense as the linear combination of three variables: (a) a score of the number of items that participants' rated as applying to both consultants and advocates (Both), (b) a separate score of the number of items rated as only applying to advocates (Advocate), and (c) a final score of the number of items rated as only applying to consultants (Consultant).

The authors were mindful that differences in training, professional experience, gender, and level of exposure to the resources used to create the survey were potentially confounding variables that may affect the survey results. Though all of these variables would be useful to investigate in their own right, the authors wanted to hold these factors constant to promote clarity of analysis and to simplify the interpretation of results. Some may question the value of holding constant the participant level of exposure to the resources used to create the survey (indicated by selecting Neither for any of the survey items). The authors believe this is valid given that the items on the survey were closely paraphrased from sources accepted as primary materials for conceptualizing best practice in consultation and social justice advocacy. For instance, item 10 on the survey states: 'Negotiates for consumers' resources access by mediating between consumers and community gatekeepers.' This item synthesizes the statement "Negotiate relevant services and education systems on behalf of clients and students" (Lewis et al., 2003, para. 2) from the ACA Advocacy Competencies and statements by Brown (1993) on linking consultees to appropriate resources. A participant that believed negotiating access to resources is a practice that neither a consultant nor an advocate would do is either unfamiliar with the resources used to create the survey or disagrees with the authors of the resources used to create the survey for reasons beyond the scope of the current study. Hence, the authors sought to remove this as a factor by holding constant responses of Neither to any of the survey items.

\section{Results}

\section{Descriptive Results}

For the entire participant sample $(n=203)$, the average number of statements rated as Both was $M=12.2(S D=4.8)$, with a range of 1 to 23 . The average number of statements rated as Consultant was $M=5.0(S D=3.5)$, with a range of 0 to 16 . The average number of statements rated as Advocate was $M=4.0(S D=2.64)$ with a range of 0 to 12 . The average number of statements rated as Neither was $M=1.1(S D=2.1)$ with a range of 0 to 20 . The mean and standard deviation is not reported on Table 2 for the single participant that indicated being of Asian ancestry. 
To address the research questions of whether counselors view consultation and social justice advocacy as similar and in what ways, the items of the Consultation and Social Justice Survey were reviewed (see Table 3). A majority of participants rated items related to working on behalf of clients (items 2, 8, and 12), using basic counseling skills (items 1, 9, 11, 17, \& 19), using problem-solving and solution-identification (items 3, 5 \& 15), and contextualizing client and student concerns in relation to oppression (items $4,6, \& 14$ ) as practices in which both consultants and advocates would engage. All items did prompt participant responses of Both, Consultant, Advocate, or Neither, with the selection of Neither being the consistently most infrequent selection (Table 3). A majority of participants $(n=119,56.9 \%)$ believed that conducting behavioral analysis was a practice in which only consultants would engage. Similarly, a majority of participants identified diagnosing problem behaviors $(n=98,46.9 \%)$ and most commonly identified negotiating for resource access $(n=115,55 \%)$ as specific to consultation. Finally, a majority of participants $(n=125,59.8 \%)$ felt that engaging in direct action was a practice in which only advocates would engage. See Table 3 for more detail.

\section{MANCOVA}

A full factorial MANCOVA analysis was conducted to investigate if group differences in the participants' perceived similarity between consultation and social advocacy could be attributed to ethnic or racial identification or practice setting, controlling for the effects of years of experience, education, gender, and lack of familiarity with the resources used to create the Consultation and Social Justice Survey. A significance level of $\alpha=.05$ was used to determine significance; a more stringent level was deemed unwarranted as this study is exploratory in nature. The interaction of participant ethnic or racial identification and practice setting (Wilk's $\lambda$ $=.824$ ) on the perceived similarity between consultation and advocacy was found to be significant at an $\alpha$ of $.05(p=.021)$. There was also a significant main effect for practice setting (Wilk's $\lambda=.900)$ at an $\alpha$ of $.05(p=.43)$. See table 4 for more detail on the results of the MANCOVA.

\section{Discussion}

Based on the descriptive results, the participants in this study perceived both similarities and differences between consultation and social justice advocacy by rating items derived from synthesis of resources from the literatures bases on these two important frameworks. As indicated in the results section, the majority of participants identified practices related to (a) using basic counseling skills, (b) problem-solving, (c) acting on behalf of clients, and (d) contextualizing client or student issues as a practice that both consultants and advocates would do. Practices related to diagnosing, using behavioral analysis, negotiating for resource access, and evaluating outcomes were rated frequently by participants as behaviors in which only consultants would engage. Using direct action to facilitate social change was rated more frequently by participants as a practice in which only advocates would engage. These findings suggest avenues for future research to determine how counselors who relate to the identified behaviors clarify what practices or competencies are important to include in an integrated model of social justice consultation. For example, would such a model include diagnosis as an important competency, or should diagnosis be avoided by counselors acting as social justice consultants? A majority of participants identified negotiating for access to resources as a practice in which only consultants would engage. This is interesting given the emphasis on acting to promote equitable access to resources found in the social justice advocacy literature 
(Crethar et al., 2008; Vera \& Speight, 2003) and specifically in the ACA Advocacy Competencies (Lewis et al., 2003). Finally, an interesting finding at the descriptive level is that each item was rated as a behavior in which neither consultants nor advocates would engage by at least one participant. This may imply lack of familiarity with available resources on the topics of consultation and social justice advocacy, or even disagreement by counselors with the ideas put forth in the extant literature. The authors hesitate to theorize on the possible sources of disagreement, but incorporating the views of counselors in disagreement with established models of consultation and of social justice advocacy would be an important contribution to future research efforts.

Though interpretation of the multivariate findings from the present study indicate that counselors' ethnic or racial identification and their practice setting may both influence how counselors would react to an integrated model of social justice consultation, an examination of the univariate $F$ tests interpreted post-hoc reveal no significant between group differences. It is difficult to interpret this finding in light of the limitations of the present study, but it could indicate that differences in practice setting and ethnic or racial identification have less effect on counselors' perceptions of similarity between consultation and social justice advocacy when not given the opportunity to classify a given practice as a behavior that only consultants or advocates would engage in (as opposed to both). Presentation of a future model of social justice consultation may need to directly emphasize role clarification in comparison to models or practices of established consultation and social justice advocacy frameworks. The authors hesitate to interpret these findings more in-depth as the present study was conceived as exploratory. The statistics used to examine the data are viewed as useful for clarifying how and in what ways the participants' perceived similarity between consultation and social justice advocacy based on their review of an abridged set of practices. This includes exploration of whether ethnic or racial identification and practice setting could be useful variables to investigate or to theorize on by other scholars interested in how social justice and consultation may intersect.

\section{Limitations and Future Directions}

Due to the method of data collection and related inability to determine an exact response rate, it is difficult to generalize the findings from the present study beyond populations that do not closely fit the characteristics of study participants. The authors believe it is likely that participants with an interest in the topics of consultation and social justice specifically, or that were more responsive to the idea that these two models were similar, comprised the majority of participants. The views of counselors disinterested in the topics of consultation and social justice, or who view these frameworks as incompatible, would be a valuable contribution to the literature base. Lack of generalizability due to special characteristics of study participants is a common flaw of survey research in general and of Internet-based surveys in particular (Granello $\&$ Wheaton, 2004). While the authors believe that the survey instrument itself is sound, it only was comprised of a small number of face-valid items derived from the literature; different results would be likely if another sample of counselors were given a more exhaustive list of practices to rate. A factor-analysis of a comprehensive list of practices would be useful to identify other patterns in how counselors might react to an integrated model of social justice consultation and what assumptions or activities would serve as the basis for said model. 


\section{Conclusion}

The participants of the present study generally supported the idea that consultation and social justice advocacy could overlap in specific areas. Scholars attempting to develop a model of social justice consultation may find certain practices are easier to integrate, such as those based on acting on behalf of clients or students, engaging in collaborative problem solving, or using basic counseling skills in new contexts. Behaviors such as assessment, diagnosis, and engaging in direct action may require more effort to integrate or may be excluded from a social justice consultation model. Acknowledging the influences of ethnic or racial identification and of adapting to practice setting may facilitate counselors' ability to integrate social justice advocacy into their professional identity. Integrating consultation and social justice advocacy can help illumine concrete practices that counselors can implement into their daily work. Further alignment of consultation and social justice advocacy helps to maximize the potential for counseling professionals to enact services based on strength identification, the removal of barriers to growth, and the facilitation and liberation of human development.

Contact information/Correspondence:

Jeffry L. Moe, Ph.D.

University of Houston Victoria

UH System at Sugar Land

14000 University Blvd.

Sugar Land, TX 77479

moej@uhv.edu

\section{References}

Arredondo, P., Toporek, R., Brown, S., Jones, J., Locke, D. C., Sanchez, J., \& Stadler, H. (1996). Operationalization of the multicultural counseling competencies. Journal of Multicultural Counseling and Development, 24, 42-78.

Arredondo, P., Tovar-Blank, Z., \& Parham, T. (2008). Challenges and promises of becoming a culturally competent counselor in a socio-political era of change and empowerment. Journal of Counseling \& Development, 86, 261-268.

Baker, S., Robichaud, T., Dietrich, V., Wells, S., \& Schreck, R. (2009). School counselor consultation: A pathway to advocacy, collaboration, and leadership. Professional School Counseling, 12, 200-212.

Bemak, F., \& Chi-Yi Chung, R. (2008). New professional roles and advocacy strategies for school counselors: A multicultural/social justice perspective to move beyond the nice counselor syndrome. Journal of Counseling \& Development, 86, 372-381. 
Brown, D. (1993). Training consultants: A call to action. Journal of Counseling \& Development, $72,139-143$.

Brown, D., Pryzwansky, W., \& Schulte, A. (2010). Psychological consultation and collaboration: Introduction to theory and practice ( $7^{\text {th }}$ ed.). Boston, MA: Pearson.

Constantine, M., Hage, S., Kindaichi, M., \& Bryant, R. (2007). Social justice and multicultural issues: Implications for the practice and training of counselors and counseling psychologists. Journal of Counseling \& Development, 85, 24-29.

Crethar, H., Torres Rivera, E., \& Nash, S. (2008). In search of common threads: Linking multicultural, feminist, and social justice counseling paradigms. Journal of Counseling \& Development, 86, 269-278.

Dahir, C., \& Stone, C. (2009). School counselor accountability: The path to social justice and systemic change. Journal of Counseling \& Development, 87, 12-20.

Granello, D., \& Wheaton, J. (2004). Online data collection: Strategies for research. Journal of Counseling \& Development, 82, 387-393.

Hays, D., Dean, J., \& Chang, C. (2007). Addressing privilege and oppression in counselor training and practice: A qualitative analysis. Journal of Counseling \& Development, 85, 317-324.

Holcomb-McCoy, C., \& Bryan, J. (2010). Advocacy and empowerment in parent consultation: Implications for theory and practice. Journal of Counseling \& Development, 88, 259-268.

Individuals with Disabilities Educational Improvement Act, 20 U.S.C. 1400. Retrieved from www.idea.ed.gov/download/statute.

Kampwirth, T.J. (2006). Collaborative consultation in the schools. ( $3^{\text {rd }}$ ed.). Upper Saddle River, $\mathrm{NJ}$ : Merrill.

Kurpius, D., \& Fuqua, D. (1993). Fundamental issues in defining consultation. Journal of Counseling \& Development, 71, 598-600.

Laux, J., Dupuy, P., Moe, J., Cox, J., Lambert, E., Ventura, L., Williamson, C., \& Benjamin, B. (2008). The substance abuse counseling needs of women in the criminal justice system: A needs assessment approach. Journal of Addictions \& Offender Counseling, 29, 36-48.

Lewis, J., Arnold, M., House, R., \& Toporek R. (2003). Advocacy Competencies. Retrieved from www.counseling.org/Counselors.

Ludlow, L., Enterline, S., \& Cochran-Smith, M. (2008). Learning to Teach for Social Justice Beliefs-Scale: An application of Rasch measurement principles. Measurement \& Evaluation in Counseling \& Development, 40, 195-214.

Lusky, M., \& Hayes, R. (2001). Collaborative consultation and program evaluation. Journal of Counseling \& Development, 79, 26-35. 
Moe, J., \& Perera-Diltz, D. (2009). An overview of systemic-organizational consultation for professional counselors. Journal of Professional Counseling: Practice, Theory, \& Research, 27, 27-37.

Nelson-Jones, R. (2002). Diverse goals for multicultural counselling and therapy. Counselling Psychology Quarterly, 15, 133-144.

Prilleltensky, I., \& Prilleltensky, O. (2003). Synergies for wellness and liberation in counseling psychology. The Counseling Psychologist, 31, 273-281.

Ratts, M., \& Hutchins, A. (2009). ACA advocacy competencies: Social justice advocacy at the client/student level. Journal of Counseling \& Development, 87, 269-275.

Roysircar, G. (2009). The big picture of advocacy: Counselor, heal society and thyself. Journal of Counseling \& Development, 87, 288-294.

Smith, S., Ng, K., Brinson, J., \& Mityagin, E. (2008). Multiculturalism, diversity, and social advocacy: A 17-year content analysis of counselor education and supervision. Counselor Education \& Supervision, 47, 249-263.

Vera, E., \& Speight, S. (2003). Multicultural competence, social justice, and counseling psychology: Expanding our roles. The Counseling Psychologist, 31, 253-272.

Weinrach, S., \& Thomas, K. (2004). The AMCD multicultural counseling competencies: A critically-flawed initiative. Journal of Mental Health Counseling, 26, 81-93.

Zalaquett, C., Fuerth, K., Stein, C., Ivey, A., \& Ivey, M. (2009). Reframing the DSM-IV-TR from a multicultural/social justice perspective. Journal of Counseling \& Development, 86, 364371. 
Table 1: Textual Sources for Consultation and Social Justice Survey Items

Survey Items

1. Uses rapport-building skills to facilitate problem identification.

2. Acts on behalf of consumer.

3. Empowers consumer to identify solutions.

4. Facilitates the clarification of situational and contextual factors affecting the consumer.

5. Suggests multiple possible solutions to help consumers' resolve identified problems.

6 Affirms the impact of socio-political and cultural factors on human development.

7. Conducts behavioral analysis.

8. Works to increases consumer access to resources.

9. Experiences a genuine, empathic connection to consumer dilemmas and issues.

10. Negotiates for consumers' resources access by mediating between consumers and community gatekeepers.

11. Utilizes interview techniques to acquire data.

12. Identifies, challenges, and confronts institutional barriers to optimum human development.
Textual Source(s) from Reference List

Brown et al. (2010);

Crethar et al. (2008);

Holcomb-McCoy \& Bryan (2010)

Lewis et al. (2003);

Brown et al. (2010)

Kampwirth (2006);

Lusky \& Hayes (2001)

Lewis et al.(2003);

Brown et al. (2010);

Individuals with Disabilities Educational

Improvement Act (2007)

Lewis et al.(2003);

Brown et al. (2010);

Crethar et al. (2008)

Brown et al. (2010);

Crethar et al. (2008)

Brown (1993);

Individuals with Disabilities Educational

Improvement Act (2007);

Kampwirth (2006)

Lewis et al.(2003);

Lusky \& Hayes (2001)

Crethar et al. (2008);

Brown et al. (2010);

Lusky \& Hayes (2001)

Lewis et al. (2003);

Brown et al. (2010)

Brown (1993)

Lusky \& Hayes (2001)

Brown et al. (2010);

Crethar et al. (2008) 
13. Diagnoses problem behaviors.

14. Frames consumer issues as normal responses to systemic and institutional oppression.

15. Makes decisions about how to best implement solutions.

16. Trains consumers in self-advocacy strategies.

17. Recognizes and addresses sources of resistance.

18. Collects data to assess the outcome of interventions.

19. Follows up with consumers.

20. Engages in direct action to facilitate social change.

21. Is personally and directly affected by the outcomes of change efforts.
Lewis et al. (2003);

Brown et al. (2010)

Brown et al. (2010);

Kampwirth (2006);

Zalaquett, Fuerth, Stein, Ivey, \& Ivey (2008)

Crethar et al. (2008);

Lusky \& Hayes (2001)

Brown et al. (2010);

Holcomb-McCoy \& Bryan (2010)

Brown et al. (2010);

Kampwirth (2006)

Lewis et al. (2003);

Lusky \& Hayes (2001)

Brown et al. (2010);

Holcomb-McCoy \& Bryan (2010)

Lewis et al. (2003);

Holcomb-McCoy \& Bryan (2010)

Crethar et al. (2008);

Lusky \& Hayes (2001) 
Table 2: Means and standard deviations of participant ratings by ethnic or racial identification and practice setting

\begin{tabular}{|c|c|c|c|c|c|c|c|c|c|}
\hline \multirow{2}{*}{$\begin{array}{l}\text { Variabl } \\
\text { Race }\end{array}$} & & \multicolumn{2}{|c|}{ Consultant } & \multicolumn{2}{|c|}{ Advocate } & \multicolumn{2}{|c|}{ Both } & \multicolumn{2}{|c|}{ Neither } \\
\hline & & (M) & $(S D)$ & $(M)$ & $(S D)$ & $(M)$ & $(S D)$ & (M) & $(S D)$ \\
\hline & African $(n=7)$ & 5.7 & 5.4 & 5.0 & 3.5 & 11.1 & 6.4 & 1.1 & 1.0 \\
\hline & Asian $(n=1)$ & . & . & . & . & . & . & . & . \\
\hline & Euro $(n=172)$ & 4.9 & 3.3 & 4.3 & 2.6 & 12.2 & 4.7 & 1.5 & 2.3 \\
\hline & Latino $(n=14)$ & 5.7 & 4.4 & 3.1 & 2.3 & 13.2 & 4.9 & .86 & 1.1 \\
\hline & Tribal $(n=3)$ & 5.3 & 4.2 & 4.3 & 2.5 & 13.0 & 3.5 & .33 & .57 \\
\hline & Multiple Heritage $(n=6)$ & 5.3 & 5.1 & 4.7 & 4.5 & 10.1 & 7.1 & 2.2 & 2.6 \\
\hline \multicolumn{10}{|c|}{ Practice Setting } \\
\hline & Comm. $(n=57)$ & 7.3 & 1.1 & 5.4 & .85 & 9.2 & 1.6 & 1.1 & .72 \\
\hline & School $(n=63)$ & 5.3 & 1.3 & 2.5 & .97 & 14.0 & 1.8 & 1.2 & .82 \\
\hline & Couns. Ed. $(n=43)$ & 4.8 & 1.3 & 6.6 & .99 & 9.6 & 1.8 & 1.9 & .84 \\
\hline & Career $(n=15)$ & 7.6 & 1.4 & 2.1 & 1.1 & 12.5 & 2.0 & .86 & .94 \\
\hline & $\operatorname{AoD}(n=10)$ & 5.4 & 1.8 & 5.2 & 1.4 & 10.7 & 2.6 & 1.7 & 1.2 \\
\hline & Student $(n=15)$ & 2.8 & 1.5 & 4.3 & 1.2 & 15.2 & 2.1 & .71 & .91 \\
\hline \multicolumn{2}{|c|}{ Overall Total $(n=203)$} & 5.0 & 3.5 & 4.3 & 2.6 & 12.2 & 4.8 & 1.5 & 2.1 \\
\hline
\end{tabular}


Table 3: Consultation and Social Justice Survey responses and percentage of total sample $(\mathbf{n}=\mathbf{2 0 3})$

\begin{tabular}{|c|c|c|c|c|}
\hline \multirow[t]{2}{*}{ Survey Item } & \multicolumn{2}{|c|}{ Response } & \multirow[b]{2}{*}{ Advocate } & \multirow[b]{2}{*}{ Neither } \\
\hline & Both & Consultant & & \\
\hline $\begin{array}{l}\text { 1. Uses rapport-building skills to facilitate } \\
\text { problem identification. }\end{array}$ & $\begin{array}{l}142 \\
(67.9 \%)\end{array}$ & $\begin{array}{l}50 \\
(23.9 \%)\end{array}$ & $\begin{array}{l}8 \\
(3.8 \%)\end{array}$ & $\begin{array}{l}9 \\
(4.3 \%)\end{array}$ \\
\hline 2. Acts on behalf of consumer. & $\begin{array}{l}112 \\
(53.6 \%)\end{array}$ & $\begin{array}{l}5 \\
(2.4 \%)\end{array}$ & $\begin{array}{l}90 \\
(43.1 \%)\end{array}$ & $\begin{array}{l}2 \\
(1.0 \%)\end{array}$ \\
\hline $\begin{array}{l}\text { 3. Empowers consumer to identify } \\
\text { solutions. }\end{array}$ & $\begin{array}{l}131 \\
(62.7 \%)\end{array}$ & $\begin{array}{l}33 \\
(15.8 \%)\end{array}$ & $\begin{array}{l}43 \\
(20.6 \%)\end{array}$ & $\begin{array}{l}2 \\
(1 \%)\end{array}$ \\
\hline $\begin{array}{l}\text { 4. Facilitates the clarification of situational } \\
\text { and contextual factors affecting the } \\
\text { consumer. }\end{array}$ & $\begin{array}{l}123 \\
(58.9 \%)\end{array}$ & $\begin{array}{l}67 \\
(32.1 \%)\end{array}$ & $\begin{array}{l}18 \\
(8.6 \%)\end{array}$ & $\begin{array}{l}1 \\
(.5 \%)\end{array}$ \\
\hline $\begin{array}{l}\text { 5. Suggests multiple possible solutions to } \\
\text { help consumers' resolve identified } \\
\text { problems. }\end{array}$ & $\begin{array}{l}123 \\
(58.9 \%)\end{array}$ & $\begin{array}{l}70 \\
(33.5 \%)\end{array}$ & $\begin{array}{l}10 \\
(4.8 \%)\end{array}$ & $\begin{array}{l}6 \\
(2.9 \%)\end{array}$ \\
\hline $\begin{array}{l}6 \text { Affirms the impact of socio-political and } \\
\text { cultural factors on human development. }\end{array}$ & $\begin{array}{l}125 \\
(59.8 \%)\end{array}$ & $\begin{array}{l}27 \\
(12.9 \%)\end{array}$ & $\begin{array}{l}44 \\
(21.1 \%)\end{array}$ & $\begin{array}{l}13 \\
(6.2 \%)\end{array}$ \\
\hline 7. Conducts behavioral analysis. & $\begin{array}{l}53 \\
(25.4 \%)\end{array}$ & $\begin{array}{l}119 \\
(56.9 \%)\end{array}$ & $\begin{array}{l}7 \\
(3.3 \%)\end{array}$ & $\begin{array}{l}30 \\
(14.4 \%)\end{array}$ \\
\hline $\begin{array}{l}\text { 8. Works to increases consumer access to } \\
\text { resources. }\end{array}$ & $\begin{array}{l}106 \\
(50.7 \%)\end{array}$ & $\begin{array}{l}90 \\
(43.1 \%)\end{array}$ & $\begin{array}{l}11 \\
(5.3 \%)\end{array}$ & $\begin{array}{l}2 \\
(1 \%)\end{array}$ \\
\hline $\begin{array}{l}\text { 9. Experiences a genuine, empathic } \\
\text { connection to consumer dilemmas and } \\
\text { issues. }\end{array}$ & $\begin{array}{l}145 \\
(69.4 \%)\end{array}$ & $\begin{array}{l}14 \\
(6.7 \%)\end{array}$ & $\begin{array}{l}43 \\
(20.6 \%)\end{array}$ & $\begin{array}{l}7 \\
(3.3 \%)\end{array}$ \\
\hline $\begin{array}{l}\text { 10. Negotiates for consumers' resources } \\
\text { access by mediating between consumers } \\
\text { and community gatekeepers. }\end{array}$ & $\begin{array}{l}82 \\
(39.5 \%)\end{array}$ & $\begin{array}{l}115 \\
(55.0 \%)\end{array}$ & $\begin{array}{l}7 \\
(3.3 \%)\end{array}$ & $\begin{array}{l}5 \\
(2.5 \%)\end{array}$ \\
\hline $\begin{array}{l}\text { 11. Utilizes interview techniques to } \\
\text { acquire data. }\end{array}$ & $\begin{array}{l}151 \\
(72.2 \%)\end{array}$ & $\begin{array}{l}48 \\
(23.0 \%)\end{array}$ & $\begin{array}{l}4 \\
(1.9 \%)\end{array}$ & $\begin{array}{l}6 \\
(2.9 \%)\end{array}$ \\
\hline $\begin{array}{l}\text { 12. Identifies, challenges, and confronts } \\
\text { institutional barriers to optimum human } \\
\text { development. }\end{array}$ & $\begin{array}{l}122 \\
(58.4 \%)\end{array}$ & $\begin{array}{l}17 \\
(8.1 \%)\end{array}$ & $\begin{array}{l}67 \\
(32.1 \%)\end{array}$ & $\begin{array}{l}3 \\
(1.4 \%)\end{array}$ \\
\hline 13. Diagnoses problem behaviors. & $\begin{array}{l}61 \\
(29.2 \%)\end{array}$ & $\begin{array}{l}98 \\
(46.9 \%)\end{array}$ & $\begin{array}{l}8 \\
(3.8 \%)\end{array}$ & $\begin{array}{l}42 \\
(20.1 \%)\end{array}$ \\
\hline
\end{tabular}


14. Frames consumer issues as normal responses to systemic and institutional oppression.

15. Makes decisions about how to best implement solutions.

16. Trains consumers in self-advocacy strategies.

17. Recognizes and addresses sources of resistance.

18. Collects data to assess the outcome of interventions.

19. Follows up with consumers.

20. Engages in direct action to facilitate social change.

21. Is personally and directly affected by the outcomes of change efforts.

\begin{tabular}{|llll}
96 & 66 & 26 & 21 \\
$(45.9 \%)$ & $(31.6 \%)$ & $(12.4 \%)$ & $(10.0 \%)$ \\
108 & 49 & 21 & 31 \\
$(51.7 \%)$ & $(23.4 \%)$ & $(10.0 \%)$ & $(14.8 \%)$ \\
122 & 23 & 59 & 5 \\
$(58.4 \%)$ & $(11.0 \%)$ & $(28.2 \%)$ & $(2.4 \%)$ \\
146 & 47 & 8 & 8 \\
$(69.9 \%)$ & $(22.5 \%)$ & $(3.8 \%)$ & $(3.8 \%)$ \\
99 & 90 & 5 & 15 \\
$(47.4 \%)$ & $(43.1 \%)$ & $(2.4 \%)$ & $(7.2 \%)$ \\
157 & 28 & 14 & 10 \\
$(75.1 \%)$ & $(13.4 \%)$ & $(6.7 \%)$ & $(4.8 \%)$ \\
71 & 9 & 125 & 4 \\
$(34.0 \%)$ & $(4.3 \%)$ & $(59.8 \%)$ & $(1.9 \%)$ \\
96 & 9 & 44 & 60 \\
$(45.9 \%)$ & $(4.3 \%)$ & $(21.1 \%)$ & $(28.7 \%)$ \\
& & &
\end{tabular}


Table 4: MANCOVA for the effects of practice setting and ethnic or racial identification on perceived similarity between consultation and social justice advocacy controlling for years of experience, years of education, gender, and unfamiliarity with resources use to create survey $(n=203)$

Grouping Variables

Ethnic or racial identification .89

PS

Ethnic or racial identification*PS $.021 *$
Wilk's $\lambda$

.90

$(10,354)$

.83

.97

$d f$
F

$(10,354)$

.51

1.96

$.043^{*}$

$(20,354)$

Note: $\mathrm{PS}=$ practice setting

$* p<.05$ 